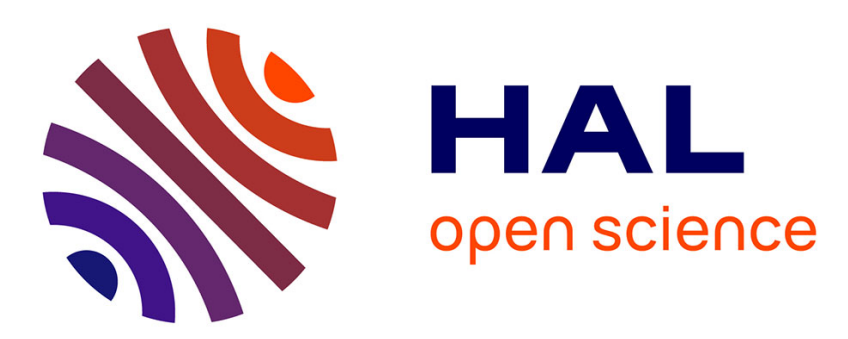

\title{
Study of oxygen-rare gas collisions by depolarized Raman scattering
}

\author{
M. Berard, J.-P. Cebe, M. Giraud, P. Lallemand
}

\section{To cite this version:}

M. Berard, J.-P. Cebe, M. Giraud, P. Lallemand. Study of oxygen-rare gas collisions by depolarized Raman scattering. Journal de Physique Lettres, 1983, 44 (13), pp.507-516. 10.1051/jphyslet:019830044013050700 . jpa-00232224

\section{HAL Id: jpa-00232224 https://hal.science/jpa-00232224}

Submitted on 1 Jan 1983

HAL is a multi-disciplinary open access archive for the deposit and dissemination of scientific research documents, whether they are published or not. The documents may come from teaching and research institutions in France or abroad, or from public or private research centers.
L'archive ouverte pluridisciplinaire HAL, est destinée au dépôt et à la diffusion de documents scientifiques de niveau recherche, publiés ou non, émanant des établissements d'enseignement et de recherche français ou étrangers, des laboratoires publics ou privés. 
Classification

Physics Abstracts

$33.20 \mathrm{~F}-34.20$

\title{
Study of oxygen-rare gas collisions by depolarized Raman scattering
}

\author{
M. Berard $\left({ }^{+}\right)$, J.-P. Cebe $\left({ }^{++}\right)$, M. Giraud $\left({ }^{++}\right)$and P. Lallemand $\left({ }^{+}\right)$ \\ $\left({ }^{+}\right)$Laboratoire de Spectroscopie Hertzienne de l'E.N.S. $\left({ }^{*}\right)$, \\ 24, rue Lhomond, 75231 Paris Cedex 05, France \\ $\left({ }^{++}\right)$Laboratoire de Physique des Interactions Ioniques et Moléculaires $\left({ }^{* *}\right)$, \\ Université de Provence, 13997 Marseille Cedex 13, France
}

(Reçu le 23 mars 1983, accepté le 5 mai 1983)

\begin{abstract}
Résumé. - Nous avons mesuré les largeurs de raies du spectre Raman dépolarisé des mélanges oxygène-gaz rares pour des températures comprises entre $181 \mathrm{~K}$ et $373 \mathrm{~K}$ ainsi que pour des nombres quantiques de rotation de la molécule d'oxygène variant de $N=1$ à $N=25$. Nous comparons ensuite ces résultats expérimentaux avec des résultats théoriques obtenus grâce à une théorie semiclassique de l'élargissement collisionnel des raies faisant intervenir des potentiels intermoléculaires déterminés soit par des règles de combinaison soit, dans le cas du système $\mathrm{O}_{2}$-Ar, par une analyse de différentes propriétés thermodynamiques. On observe un bon accord général entre la théorie et les résultats expérimentaux présentés.
\end{abstract}

\begin{abstract}
We have measured the linewidths of depolarized rotational Raman spectra for mixtures of oxygen and noble gases such as $\mathrm{He}, \mathrm{Ne}, \mathrm{Ar}, \mathrm{Kr}$. The measurements are made from $181 \mathrm{~K}$ to $373 \mathrm{~K}$ and for rotational quantum numbers of molecular oxygen varying from $N=1$ to $N=25$. Comparison is made with calculations obtained by a semi-classical theory of line broadening using intermolecular potentials given either by combination rules or by analysis of various thermodynamic properties. We observe a generally good agreement between the experimental data and the theoretical results.
\end{abstract}

\section{Introduction.}

An efficient way of getting information about the anisotropic part of intermolecular potentials is to study the pressure broadening of depolarized Raman lines, and in particular of the pure rotational Raman spectrum [1]. In the past some experimental results have been obtained for $\mathrm{N}_{2}$ and $\mathrm{O}_{2}$ mixed with rare gases. In addition much work has been done on hydrogen and its isotopes [2], but the large value of its rotational constant leads to interpretations qualitatively different from that of heavier diatomic molecules. Following our previous work on pure oxygen [3] which was published in a paper referred to as I, we shall present here detailed experimental results

(*) L.A. $n^{\circ} 18$.

$\left({ }^{* *}\right)$ E.R.A. $n^{\circ} 898$,

associated with the "Centre National de la Recherche Scientifique». 
for the pressure broadening coefficient of pure rotational Raman lines of oxygen due to collisions with rare gases. We shall then compare those results with theoretical values that we have obtained in the framework of the Smith-Giraud-Cooper (SGC) semiclassical theory [4], using as intermolecular potential a modified Buckingham potential, the parameters of which are deduced from combination rules similar to those considered when interpreting transport coefficients. As both the experimental method and the theoretical analysis are the same as those discussed in I, we shall not describe them here uniless there are significant differences between the study of $\mathrm{O}_{2}-\mathrm{O}_{2}$ collisions and that of $\mathrm{O}_{2}$-rare gases collisions.

\section{Experiment.}

The pressure broadening coefficients were measured for mixtures of oxygen and rare gases containing roughly $1 / 3$ oxygen. Using the same data analysis an in $I$, we measured linewidths $\Gamma_{\text {mix }}$ which were expressed as

$$
\Gamma_{\text {mix }}=\rho\left[Y \gamma_{\mathrm{O}_{2}-\mathrm{O}_{2}}+(1-Y) \gamma_{\mathrm{O}_{2}-\mathrm{X}}\right]
$$

where $\rho$ is the density of the mixture and $Y$ is the molar concentration of the mixture. The accuracy of $Y$ is better than $1 \%$ (mixtures were prepared by Air Liquide). The values of $\gamma_{\mathrm{O}_{2}-\mathrm{O}_{2}}$ were measured previously in $\mathrm{I}$, or interpolated from those measurements when the present temperatures were not very close to those studied in $\mathrm{I}$. The uncertainty of $\gamma_{\mathrm{O}_{2-} \mathrm{X}}$ is larger than that of $\gamma_{\mathrm{O}_{2}-\mathrm{O}_{2}}$ mostly because the signal was reduced due to the smaller amount of oxygen molecules for a given total density. The relative accuracy of the present results is of the order of $4 \%$ for the most intense lines at room temperature and $7 \%$ for weak lines.

We shall present our experimental results in tables III, IV, V and VI together with theoretical values respectively for $\mathrm{He}, \mathrm{Ne}, \mathrm{Ar}$ and $\mathrm{Kr}$. One can see that the rate of change of $\gamma_{\mathrm{O}_{2}-\mathrm{X}}$ with the rotational quantum number $N$ is large when $X$ is heavy and is small when the temperature is lower. Moreover one can note that the experimental linewidths decrease when the temperature increases, and that the lighter are the perturbers, the smaller are the linewidths. We can also mention that, when compared to the previous results of Jammu et al. [5], our experimental results are larger by about $14 \%$, probably for the same reasons as discussed in I.

\section{Interpretation of the experimental results.}

Apart from complications in the rotational spectrum due to the non zero value of the electronic spin of the oxygen molecule in the ${ }^{3} \Sigma_{\mathrm{g}}^{-}$state, the $\mathrm{O}_{2}$-rare gas system is quite simple and should be amenable to useful discussions with regard to the interactions that influence depolarized Raman lines. This system has been studied from a purely classical point of view by Mingelgrin and Gordon [6] (MG). Here we shall use a semi-classical approach due to Smith, Giraud and Cooper (SGC) which was previously extended to the case of oxygen microwave spectrum by Smith and Giraud [7] and to the case of depolarized Raman lines by Cebe, Giraud and Smith [8] and by the present authors [3]. We shall first consider the case $\mathrm{O}_{2}-\mathrm{Ar}$ at room temperature in order to compare the classical results of MG and the semi-classical ones of SGC using the same intermolecular potential. We shall then consider the cases corresponding to the present experimental results.

As is well known [9], the pressent problem involves both methodological difficulties due to the use of various approximations and the knowledge of an interatomic potential. This second point has a major influence on the theoretical predictions. Here we shall not try to make an exhaustive search for potentials, but we shall limit ourselves to the use of modified Buckingham potentials of the form

$$
V(r, \theta)=V_{0}(r)+V_{2}(r) P_{2}(\cos \theta)
$$


Here $r$ is the distance between the centres of mass of the two colliding systems, $\theta$ the angle between the internuclear axis of the oxygen molecule and the axis of the centres of mass, finally $P_{2}$ is a Legendre polynomial of order 2 . We shall take $V_{0}(r)$ and $V_{2}(r)$ such as :

$$
\begin{aligned}
& V_{0}(r)=V_{\text {rep }}(r)-V_{\text {att }}(r), \\
& V_{2}(r)=a_{\mathrm{r}} V_{\text {rep }}(r)-a_{\mathrm{a}} V_{\text {att }}(r),
\end{aligned}
$$

with

$$
\begin{aligned}
& V_{\text {rep }}(r)=\varepsilon \frac{6}{\alpha-6} \exp \left(-\alpha\left(r / r_{\mathrm{m}}-1\right)\right) \\
& V_{\text {att }}(r)=\varepsilon \frac{\alpha}{6-\alpha}\left(r_{\mathrm{m}} / r\right)^{6}
\end{aligned}
$$

3.1 Comparison With the Results of Mingelgrin and Gordon IN THE CASE OF THE OXYGEN-ARGON SYSTEM. - We shall first take for the parameters $\varepsilon, \alpha, r_{\mathrm{m}}, a_{\mathrm{r}}$ and $a_{\mathrm{a}}$ the values chosen by MG. Those are $\varepsilon=157 \mathrm{~K}, \alpha=18.67, r_{\mathrm{m}}=3.661 \AA, a_{\mathrm{r}}=1.21$ and $a_{\mathrm{a}}=0.220$. We show in table I both our results and those of MG. One can see that both methods lead essentially to the same values in the domain where MG give numbers. This result is not surprising as the SGC method should be quite reliable at large $N$. We may recall here that the SGC method has also been tested against other semi-classical calculations involving fewer approximations. This means that the SGC method provides reliable theoretical predictions. From this one can now interpret the differences between MG and SGC for the case of $\mathrm{O}_{2}-\mathrm{O}_{2}$ collisions presented in table IV of $I$ in the following way : MG take into account the internal structure of the collision partner, whereas the SGC method does not and takes an average over the orientation of the second molecule to determine an intermolecular potential of the form of (1). This procedure is not quite satisfactory.

We then applied the SGC method for the various temperatures at which we performed experiments in the case of oxygen-argon collisions. We show the results in figure 1 for room temperature.

3.2 General CASE : COMbination RULES. - Even when taking a model for the potential like that described by equations $1-5$, we have to find values for the parameters involved. In this work we have taken values of $\alpha, r_{\mathrm{m}}$ and $\varepsilon$ which were chosen in order to fit thermodynamic data and transport coefficients. Such data are well documented for pure gases and one uses some kind of combination rules to describe mixtures. These rules are chosen to fit experimental data on mixtures when these are available. Here we shall use the rules of Kong and Chakrabarty [10]. If $\varepsilon^{i i}, \alpha^{i i}, r_{\mathrm{m}}^{i i}$ are the exp-6 potential parameters for a pair of similar systems, then the para-

Table I. - Calculated linewidth coefficient for $\mathrm{O}_{2}-\mathrm{Ar}$ at $298 \mathrm{~K}$ using the same potential and either the classical method of Mingelgrin and Gordon or the present theory.

\begin{tabular}{|c|c|c|c|c|c|}
\hline$N$ & 7 & 9 & 11 & 13 & 15 \\
\hline $\begin{array}{c}\text { M.G. } \\
\begin{array}{c}\text { Present } \\
\text { work }\end{array}\end{array}$ & 4.67 & 4.40 & 3.93 & 3.82 & 3.71 \\
\hline
\end{tabular}




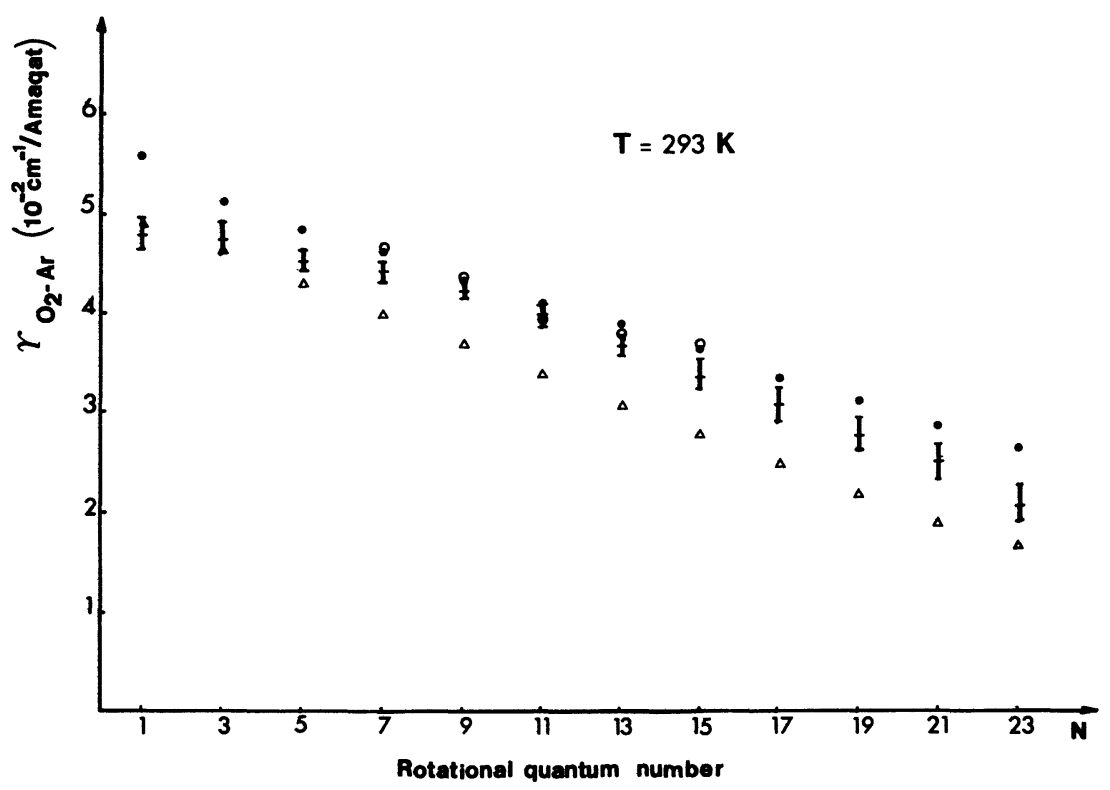

Fig. 1. - Pressure broadening coefficient for the $N \rightarrow N+2$ rotational Raman transitions of oxygen perturbed by argon at room temperature. Experimental data, this work : $f$. Theoretical values, reference 6 : $O$; this work with combination rules parameters : $\bullet$; this work with reference. 13 parameters $: \Delta$.

meters for different systems are given by

$$
\begin{aligned}
{\left[\frac{\varepsilon^{i j} \alpha^{i j} \mathrm{e}^{\alpha^{i j}}}{\left(\alpha^{i j}-6\right) r_{\mathrm{m}}^{i j}}\right]^{2 r_{\mathrm{m}}^{i j / \alpha^{i j}}} } & =\left[\frac{\varepsilon^{i i} \alpha^{i i} \mathrm{e}^{\alpha^{i i}}}{\left(\alpha^{i i}-6\right) r_{\mathrm{m}}^{i i}}\right]^{r_{m}^{i / \alpha^{i i}}} \cdot\left[\frac{\varepsilon^{j j} \alpha^{j j} \mathrm{e}^{\alpha^{j j}}}{\left(\alpha^{j j}-6\right) r_{\mathrm{m}}^{j j}}\right]^{r_{\mathrm{m}}^{j j / \alpha^{j j}}} \\
\frac{r_{\mathrm{m}}^{i j}}{\alpha^{i j}} & =\frac{1}{2}\left[\frac{r_{\mathrm{m}}^{i i}}{\alpha^{i i}}+\frac{r_{\mathrm{m}}^{j j}}{\alpha^{j j}}\right] \\
\frac{\varepsilon^{i j} \alpha^{i j}\left(r_{\mathrm{m}}^{i j}\right)^{6}}{\left(\alpha^{i j}-6\right)} & =\left[\frac{\varepsilon^{i i} \alpha^{i i}\left(r_{\mathrm{m}}^{i i}\right)^{6}}{\left(\alpha^{i i}-6\right)} \cdot \frac{\varepsilon^{j j} \alpha^{j j}\left(r_{\mathrm{m}}^{j j}\right)^{6}}{\left(\alpha^{j j}-6\right)}\right]^{1 / 2}
\end{aligned}
$$

we show in table II all the values that we have used in this work.

In all our calculations we have used for $a_{\mathrm{a}}$ the same value as in pure oxygen, that is $a_{\mathrm{a}}=0.229$. As shown in I, this parameter has but a small influence on the values of the calculated Raman linewidths. Its physical origin lies in the anisotropy of the oxygen molecule so that there is little reason that it changes with the nature of the collision partner. The repulsive part of the anisotropic potential will depend much more on the size of the collision partner, as one can describe the short range interaction as the sum of interatomic potentials between the two oxygen atoms of the oxygen molecule and the collision partner. Here we shall use the relationship proposed by Mingelgrin [11]

$$
a_{\mathrm{r}}=\frac{2.92\left(\alpha / r_{\mathrm{m}}\right)^{2}}{24+1.46\left(\alpha / r_{\mathrm{m}}\right)^{2}}
$$

The corresponding numbers are also given in table II. 
Table II. - Parameters for the $\mathrm{O}_{2}$-noble gas potentials given by equations 5-7. The attractive potential anisotropy $a_{\mathrm{a}}=0.229$ is the same for all noble gas perturbers. The pure $\mathrm{O}_{2}$ potential was obtained from Mingelgrin [11] and the pure noble gas potentials were obtained from Hoogervost [12].

\begin{tabular}{|l|c|c|c|c|}
\hline $\mathrm{Gas}$ & $\varepsilon(\mathrm{K})$ & $r_{\mathrm{m}}(\AA)$ & $\alpha$ & $a_{\mathrm{r}}$ \\
\hline $\mathrm{O}_{2}-\mathrm{O}_{2}$ & 156 & 3.68 & 19.3 & \\
$\mathrm{He}-\mathrm{He}$ & 19.7 & 2.66 & 15.9 & \\
$\mathrm{He}-\mathrm{O}_{2}$ & 48.1 & 3.21 & 17.9 & 1.31 \\
$\mathrm{Ne}-\mathrm{Ne}$ & 43.0 & 3.03 & 16.0 & \\
$\mathrm{Ne}-\mathrm{O}_{2}$ & 78.7 & 3.36 & 17.7 & 1.26 \\
$\mathrm{Ar}-\mathrm{Ar}$ & 138 & 3.77 & 14.8 & \\
$\mathrm{Ar}-\mathrm{O}_{2}$ & 147 & 3.72 & 16.7 & 1.10 \\
$\mathrm{Kr}-\mathrm{Kr}$ & 196 & 4.01 & 15.0 & \\
$\mathrm{Kr}-\mathrm{O}_{2}$ & 171 & 3.85 & 16.8 & 1.07 \\
\hline
\end{tabular}

We now present our experimental data together with the theoretical results obtained with the potentials defined by the parameters [12] shown in table II. Table III is related to helium, table IV to neon, table V to argon and table VI to krypton. A detailed analysis of the different tables shows that, for a given temperature, the slopes of the curves of the linewidths versus the rotational quantum number are steeper the heavier the collision partner is.

Classically, this phenomenon is explained by an effect of reduced mass, but in our case, as can be seen in table II, the variation of the steepness of the repulsive wall (parameter $\alpha$ ) as a function of the collision partner adds its own effect to the latter. Moreover one can see that there is a very good overall agreement between experiment and the present theory except for small $N$ and the lowest temperatures in which case the experimental accuracy is not the best (possible influence of the depolarized Rayleigh line in the former case, weaker signal in the latter). To illustrate the quality of the fit we show in figure 1 the results for oxygen-argon at room temperature.

The fact that we are able to predict correctly both the variations of the linewidths with $N$ and with the temperature shows that we have chosen adequate values for the parameters, in particular for the steepness of the repulsive potential, this parameter dominating the slope of $\gamma_{\mathrm{O}_{2}-\mathrm{X}}$ versus $\mathrm{N}$ as was shown in $\mathrm{I}$.

3.3 CASE OF a POTENTIAL DETERMined by MUlTIPROPERTY ANAlysis. - However nowadays, the potentials determined by semi-empirical rules are being superseded by those evaluated by more elaborate methods $[13,14]$ such as thermodynamic and transport properties or elaborate molecular beam experiments. It would be interesting to extend our present calculations using these new potentials. We have studied in detail the oxygen-argon case the intermolecular potential of which is given explicitly in terms of second order Legendre polynomial expansion where the radial functions $V_{0}(r)$ and $V_{2}(r)$ are determined from multiproperties analysis by Pirani et al. [13]. Our computer programs being presently optimized for an exp-6 potential, we do not use the exact form of these radial functions but we replace them by a best fit to an exp-6 form following (2), (3), (4), (5); this allows us to find the theoretical values of the Raman linewidths of the $\mathrm{O}_{2}$-Ar case that were added to figure 1 . One can see that they are not in very good agreement with experiment. This is due to two reasons : first the well depth of the isotropic part of the interaction is too small compared to that given by combination rules, this fact has been pointed out by Rotzoll [14] and the value proposed by Pirani, $\varepsilon=133.5 \mathrm{~K}$, is known to give 
Table III. - Broadening coefficients (in $10^{-2} \mathrm{~cm}^{-1}$ /amagat) of the rotational Raman transitions $N \rightarrow N+2$ for $\mathrm{O}_{2}$ perturbed by He. The first line gives the experimental value, the second line gives the value calculated with the intermolecular potential evaluated by combination rules.

\begin{tabular}{|c|c|c|c|c|c|}
\hline$N$ & 181 & 232 & 293 & 338 & 373 \\
\hline 1 & $\begin{array}{l}2.92 \\
3.26\end{array}$ & $\begin{array}{l}3.67 \\
3.70\end{array}$ & $\begin{array}{l}4.14 \\
4.17\end{array}$ & $\begin{array}{l}4.44 \\
4.49\end{array}$ & $\begin{array}{l}4.80 \\
4.72\end{array}$ \\
\hline 3 & $\begin{array}{l}2.66 \\
3.06\end{array}$ & $\begin{array}{l}3.31 \\
3.46\end{array}$ & $\begin{array}{l}3.94 \\
3.89\end{array}$ & $\begin{array}{l}4.25 \\
4.18\end{array}$ & $\begin{array}{l}4.51 \\
4.40\end{array}$ \\
\hline 5 & $\begin{array}{l}2.58 \\
2.94\end{array}$ & $\begin{array}{l}3.16 \\
3.31\end{array}$ & $\begin{array}{l}3.83 \\
3.71\end{array}$ & $\begin{array}{l}3.93 \\
3.99\end{array}$ & $\begin{array}{l}4.29 \\
4.19\end{array}$ \\
\hline 7 & $\begin{array}{l}2.60 \\
2.88\end{array}$ & $\begin{array}{l}3.24 \\
3.24\end{array}$ & $\begin{array}{l}3.77 \\
3.62\end{array}$ & $\begin{array}{l}3.94 \\
3.89\end{array}$ & $\begin{array}{l}4.28 \\
4.08\end{array}$ \\
\hline 9 & $\begin{array}{l}2.60 \\
2.82\end{array}$ & $\begin{array}{l}3.18 \\
3.18\end{array}$ & $\begin{array}{l}3.62 \\
3.56\end{array}$ & $\begin{array}{l}3.89 \\
3.82\end{array}$ & $\begin{array}{l}4.26 \\
4.01\end{array}$ \\
\hline 11 & $\begin{array}{l}2.47 \\
2.75\end{array}$ & $\begin{array}{l}3.06 \\
3.11\end{array}$ & $\begin{array}{l}3.51 \\
3.50\end{array}$ & $\begin{array}{l}3.82 \\
3.76\end{array}$ & $\begin{array}{l}4.22 \\
3.95\end{array}$ \\
\hline 13 & $\begin{array}{l}2.46 \\
2.67\end{array}$ & $\begin{array}{l}2.95 \\
3.04\end{array}$ & $\begin{array}{l}3.40 \\
3.43\end{array}$ & $\begin{array}{l}3.74 \\
3.69\end{array}$ & $\begin{array}{l}4.13 \\
3.88\end{array}$ \\
\hline 15 & $\begin{array}{l}2.30 \\
2.58\end{array}$ & $\begin{array}{l}2.79 \\
2.95\end{array}$ & $\begin{array}{l}3.37 \\
3.35\end{array}$ & $\begin{array}{l}3.67 \\
3.61\end{array}$ & $\begin{array}{l}4.00 \\
3.81\end{array}$ \\
\hline 17 & $\begin{array}{l}2.21 \\
2.48\end{array}$ & $\begin{array}{l}2.74 \\
2.86\end{array}$ & $\begin{array}{l}3.30 \\
3.26\end{array}$ & $\begin{array}{l}3.64 \\
3.53\end{array}$ & $\begin{array}{l}3.91 \\
3.73\end{array}$ \\
\hline 19 & $\begin{array}{l}2.17 \\
2.37\end{array}$ & $\begin{array}{l}2.70 \\
2.76\end{array}$ & $\begin{array}{l}3.27 \\
3.17\end{array}$ & $\begin{array}{l}3.61 \\
3.44\end{array}$ & $\begin{array}{l}3.82 \\
3.65\end{array}$ \\
\hline 21 & & $\begin{array}{l}2.69 \\
2.65\end{array}$ & $\begin{array}{l}3.21 \\
3.07\end{array}$ & $\begin{array}{l}3.54 \\
3.35\end{array}$ & $\begin{array}{l}3.80 \\
3.56\end{array}$ \\
\hline 23 & & & $\begin{array}{l}3.17 \\
2.97\end{array}$ & $\begin{array}{l}3.43 \\
3.25\end{array}$ & $\begin{array}{l}3.74 \\
3.46\end{array}$ \\
\hline 25 & & & 3.16 & 3.46 & 3.72 \\
\hline
\end{tabular}

bad results in the calculations of total differential cross sections; secondly, the steepness of the repulsive wall, $\alpha=13.7$, is not large enough and gives a rather bad evaluation of the slope of the curve $\gamma_{\mathrm{O}_{2} \text {-Ar }}$ versus $N$, see figure 1 , as we have shown in $I$.

Now all our work has been limited to the smallest angular dependance of the potential : we include only a term in $P_{2}$, but as shown by recent work [15], contributions from higher order Legendre polynomials should be considered. We shall discuss the influence of a contribution from $P_{4}$ in a future publication. 
Table IV. - Same as table III, but for $\mathrm{O}_{2}-\mathrm{Ne}$ couple.

\begin{tabular}{|c|c|c|c|c|c|}
\hline$N$ & 188 & 232 & 293 & 338 & 378 \\
\hline 1 & $\begin{array}{l}2.93 \\
3.50\end{array}$ & $\begin{array}{l}3.23 \\
3.75\end{array}$ & $\begin{array}{l}3.44 \\
4.01\end{array}$ & $\begin{array}{l}3.68 \\
4.19\end{array}$ & $\begin{array}{l}3.90 \\
4.32\end{array}$ \\
\hline 3 & $\begin{array}{l}2.73 \\
3.28\end{array}$ & $\begin{array}{l}3.11 \\
3.52\end{array}$ & $\begin{array}{l}3.30 \\
3.79\end{array}$ & $\begin{array}{l}3.53 \\
3.97\end{array}$ & $\begin{array}{l}3.73 \\
4.11\end{array}$ \\
\hline 5 & $\begin{array}{l}2.62 \\
3.09\end{array}$ & $\begin{array}{l}2.91 \\
3.33\end{array}$ & $\begin{array}{l}3.23 \\
3.60\end{array}$ & $\begin{array}{l}3.43 \\
3.78\end{array}$ & $\begin{array}{l}3.66 \\
3.92\end{array}$ \\
\hline 7 & $\begin{array}{l}2.59 \\
2.92\end{array}$ & $\begin{array}{l}2.88 \\
3.17\end{array}$ & $\begin{array}{l}3.15 \\
3.44\end{array}$ & $\begin{array}{l}3.36 \\
3.63\end{array}$ & $\begin{array}{l}3.60 \\
3.77\end{array}$ \\
\hline 9 & $\begin{array}{l}2.41 \\
2.75\end{array}$ & $\begin{array}{l}2.71 \\
3.01\end{array}$ & $\begin{array}{l}2.99 \\
3.29\end{array}$ & $\begin{array}{l}3.16 \\
3.48\end{array}$ & $\begin{array}{l}3.38 \\
3.63\end{array}$ \\
\hline 11 & $\begin{array}{l}2.24 \\
2.58\end{array}$ & $\begin{array}{l}2.63 \\
2.84\end{array}$ & $\begin{array}{l}2.90 \\
3.13\end{array}$ & $\begin{array}{l}3.06 \\
3.33\end{array}$ & $\begin{array}{l}3.31 \\
3.48\end{array}$ \\
\hline 13 & $\begin{array}{l}2.11 \\
2.41\end{array}$ & $\begin{array}{l}2.41 \\
2.68\end{array}$ & $\begin{array}{l}2.61 \\
2.97\end{array}$ & $\begin{array}{l}2.95 \\
3.18\end{array}$ & $\begin{array}{l}3.20 \\
3.33\end{array}$ \\
\hline 15 & $\begin{array}{l}1.88 \\
2.22\end{array}$ & $\begin{array}{l}2.19 \\
2.50\end{array}$ & $\begin{array}{l}2.53 \\
2.80\end{array}$ & $\begin{array}{l}2.77 \\
3.01\end{array}$ & $\begin{array}{l}3.08 \\
3.17\end{array}$ \\
\hline 17 & $\begin{array}{l}1.79 \\
2.04\end{array}$ & $\begin{array}{l}2.08 \\
2.32\end{array}$ & $\begin{array}{l}2.42 \\
2.63\end{array}$ & $\begin{array}{l}2.64 \\
2.84\end{array}$ & $\begin{array}{l}2.88 \\
2.99\end{array}$ \\
\hline 19 & $\begin{array}{l}1.61 \\
1.86\end{array}$ & $\begin{array}{l}1.93 \\
2.14\end{array}$ & $\begin{array}{l}2.22 \\
2.45\end{array}$ & $\begin{array}{l}2.47 \\
2.66\end{array}$ & $\begin{array}{l}2.64 \\
2.82\end{array}$ \\
\hline 21 & & $\begin{array}{l}1.77 \\
1.97\end{array}$ & $\begin{array}{l}2.04 \\
2.28\end{array}$ & $\begin{array}{l}2.32 \\
2.49\end{array}$ & $\begin{array}{l}2.48 \\
2.65\end{array}$ \\
\hline 23 & & & $\begin{array}{l}1.99 \\
2.12\end{array}$ & $\begin{array}{l}2.17 \\
2.33\end{array}$ & $\begin{array}{l}2.40 \\
2.48\end{array}$ \\
\hline 25 & & & 1.89 & 2.04 & 2.16 \\
\hline
\end{tabular}


Table V. - Same as table III, but for $\mathrm{O}_{2}$-Ar couple.

\begin{tabular}{|c|c|c|c|c|c|}
\hline$N$ & 188 & 232 & 293 & 338 & 378 \\
\hline 1 & $\begin{array}{l}4.37 \\
5.21\end{array}$ & $\begin{array}{l}4.59 \\
5.38\end{array}$ & $\begin{array}{l}4.81 \\
5.59\end{array}$ & $\begin{array}{l}5.13 \\
5.75\end{array}$ & $\begin{array}{l}5.26 \\
5.90\end{array}$ \\
\hline 3 & $\begin{array}{l}4.26 \\
4.77\end{array}$ & $\begin{array}{l}4.47 \\
4.94\end{array}$ & $\begin{array}{l}4.76 \\
5.16\end{array}$ & $\begin{array}{l}4.89 \\
5.32\end{array}$ & $\begin{array}{l}5.08 \\
5.46\end{array}$ \\
\hline 5 & $\begin{array}{l}4.16 \\
4.46\end{array}$ & $\begin{array}{l}4.31 \\
4.64\end{array}$ & $\begin{array}{l}4.55 \\
4.87\end{array}$ & $\begin{array}{l}4.70 \\
5.03\end{array}$ & $\begin{array}{l}4.89 \\
5.17\end{array}$ \\
\hline 7 & $\begin{array}{l}4.06 \\
4.20\end{array}$ & $\begin{array}{l}4.19 \\
4.38\end{array}$ & $\begin{array}{l}4.44 \\
4.62\end{array}$ & $\begin{array}{l}4.68 \\
4.79\end{array}$ & $\begin{array}{l}4.72 \\
4.93\end{array}$ \\
\hline 9 & $\begin{array}{l}3.83 \\
3.94\end{array}$ & $\begin{array}{l}4.04 \\
4.12\end{array}$ & $\begin{array}{l}4.23 \\
4.37\end{array}$ & $\begin{array}{l}4.48 \\
4.54\end{array}$ & $\begin{array}{l}4.59 \\
4.69\end{array}$ \\
\hline 11 & $\begin{array}{l}3.62 \\
3.67\end{array}$ & $\begin{array}{l}3.77 \\
3.85\end{array}$ & $\begin{array}{l}4.02 \\
4.11\end{array}$ & $\begin{array}{l}4.24 \\
4.29\end{array}$ & $\begin{array}{l}4.36 \\
4.45\end{array}$ \\
\hline 13 & $\begin{array}{l}3.26 \\
3.41\end{array}$ & $\begin{array}{l}3.53 \\
3.60\end{array}$ & $\begin{array}{l}3.67 \\
3.83\end{array}$ & $\begin{array}{l}3.94 \\
4.05\end{array}$ & $\begin{array}{l}4.07 \\
4.22\end{array}$ \\
\hline 15 & $\begin{array}{l}2.90 \\
3.16\end{array}$ & $\begin{array}{l}3.06 \\
3.36\end{array}$ & $\begin{array}{l}3.37 \\
3.64\end{array}$ & $\begin{array}{l}3.55 \\
3.84\end{array}$ & $\begin{array}{l}3.72 \\
4.00\end{array}$ \\
\hline 17 & $\begin{array}{l}2.78 \\
2.90\end{array}$ & $\begin{array}{l}2.90 \\
3.12\end{array}$ & $\begin{array}{l}3.10 \\
3.41\end{array}$ & $\begin{array}{l}3.34 \\
3.62\end{array}$ & $\begin{array}{l}3.57 \\
3.79\end{array}$ \\
\hline 19 & & $\begin{array}{l}2.69 \\
2.86\end{array}$ & $\begin{array}{l}2.82 \\
3.17\end{array}$ & $\begin{array}{l}3.05 \\
3.38\end{array}$ & $\begin{array}{l}3.16 \\
3.57\end{array}$ \\
\hline 21 & & $\begin{array}{l}2.37 \\
2.60\end{array}$ & $\begin{array}{l}2.56 \\
2.92\end{array}$ & $\begin{array}{l}2.78 \\
3.14\end{array}$ & $\begin{array}{l}3.00 \\
3.32\end{array}$ \\
\hline 23 & & & $\begin{array}{l}2.33 \\
2.66\end{array}$ & $\begin{array}{l}2.54 \\
2.87\end{array}$ & $\begin{array}{l}2.73 \\
3.07\end{array}$ \\
\hline 25 & & & 2.11 & 2.25 & 2.44 \\
\hline 27 & & & 1.83 & 1.89 & $2: 19$ \\
\hline
\end{tabular}


Table VI. - Broadening coefficients (in $10^{-2} \mathrm{~cm}^{-1}$ /amagat) of the rotational Raman transitions $N \rightarrow N+2$ for $\mathrm{O}_{2}-\mathrm{Kr}$ at $293 \mathrm{~K}$.

\begin{tabular}{|c|c|c|}
\hline$N$ & Experiment & Theory \\
\hline 1 & 4.43 & 5.92 \\
3 & 5.10 & 5.35 \\
5 & 4.74 & 5.00 \\
7 & 4.46 & 4.73 \\
9 & 4.24 & 4.44 \\
11 & 3.99 & 4.14 \\
13 & 3.54 & 3.84 \\
15 & 3.14 & 3.58 \\
17 & 2.82 & 3.33 \\
19 & 2.50 & 3.06 \\
21 & 2.11 & 2.79 \\
23 & 1.76 & 2.50 \\
25 & 1.45 & \\
27 & 1.25 & \\
\hline
\end{tabular}

\section{Conclusion.}

In this paper, we have presented a detailed analysis of the collisions between a linear molecule and a structureless system and of their influence in depolarized Raman lines. Extensive experimental data have been obtained and compared to theoretical results derived in the framework of the Smith-Giraud-Cooper semi-classical theory. This theory is well adapted to the atomdiatom case and leads to the same result as a purely classical one when applied to the oxygenargon couple at room temperature using the same intermolecular potential in both cases.

Next, we found that the Kong-Chakrabarty rules to determine the parameters of potentials leads to a very good overall agreement between theory and all the present experimental data. This work shows that accurate experimental Raman linewidths give a significant piece of information to test intermolecular potentials by comparison to theoretical results obtained from a well adapted semi-classical theory, provided that a large enough range of temperature and rotational quantum number are studied.

\section{Acknowledgments.}

One of us (JPC) would like to thank Pr. J. P. Toennies for communicating results prior to publication. 


\section{References}

[1] For a review, see SRIVASTAVA, R. P. and Zaidi, H. R. in Raman Spectroscopy of Gases and Liquids, ed. A. Weber (Springer Verlag, Berlin) 1979, chap. V.

[2] VAN Den Hout, K. P., Ph. D. Thesis, Leiden (1978).

[3] Berard, M., Cebe, J. P., Giraud, M., Lallemand, P., J. Chem. Phys. 78 (1983) 672.

[4] Smith, E. W., Giraud, M. and Cooper, J., J. Chem. Phys. 65 (1976) 1256 and J. Chem. Phys. 66 (1977) 376.

[5] Jammu, K. S., St-Johns, G. E. and Welsh, K. L., Can. J. Phys. 44 (1966) 797.

[6] Mingelgrin, U. and Gordon, R. G., J. Chem. Phys. 70 (1979) 3828.

[7] Smith, E. W. and Giraud, M., J. Chem. Phys. 71 (79) 4209.

[8] Cebe, J. P., Giraud, M. and Smith, E. W., Chem. Phys. Lett. 81 (1981) 37.

[9] Atom-Molecule Collision Theory, edited by R. B. Bernstein (Plenum Press, N. Y.) 1979.

[10] Kong, C. L. and Chakrabarty, M. R., J. Phys. Chem. 77 (1973) 2668.

[11] Mingelgrin, U., Ph. D. Thesis, Harvard (1972).

[12] Hoogervost, W., Physica 51 (1971) 59.

[13] Pirani, F. and Vecchiocattivi, F., Chem. Phys. 59 (1981) 387.

[14] Rotzoll, G., Chem. Phys. Lett. 88 (1982) 179.

[15] Faubel, M., Kohl, K. H., Toennies, J. P. and Gianturco, F. A. (to be published). 